\title{
The 1918-19 Influenza pandemic and its impact on Aboriginal people in South Australia
}

\author{
Tom Gara
}

\begin{abstract}
In this paper I discuss the origin and spread of the 1918-19 Influenza pandemic and its impact around the world, particularly on indigenous populations. I document the arrival of the disease in Australia in early 1919, and discuss the efforts made by Commonwealth and state authorities to control its spread, and its impact on Australian society. I then explore the effects of the epidemic on Aboriginal people in South Australia. My research shows that the epidemic had little impact on the more urbanised Aboriginal people in the southern part of the state but caused an alarming number of deaths when it spread to Aboriginal communities along the railway line to Oodnadatta and beyond in the middle of 1919, and when it reached the far west coast of South Australia in August.
\end{abstract}

\section{Introduction}

The year 2019 marked the centenary of the 'Spanish' Influenza pandemic reaching Australia. It is believed that the pandemic of 1918-19 killed at least 40 million people worldwide and perhaps as many as 100 million, ${ }^{1}$ easily surpassing the 20 million combatants and civilians who died during the Great War. It was the most lethal pandemic of modern times and, indeed, the most lethal since the Bubonic

1 Phillips and Killingray, 'Introduction', 4, 10, 39, 132; Johnson and Mueller, 'Updating the Accounts', 115. 
Plague, or Black Death, of the fourteenth century. While AIDS has caused about 35 million deaths over the last 4 decades, the influenza pandemic may have killed 2 or 3 times that many people in about 18 months.

It was not until the 1930s that influenza was discovered to be caused by a virus, and it was only in the 1990s that research on corpses retrieved from Arctic permafrost, and from tissue samples stored in medical museums, revealed that the 1918-19 Influenza was a mutation of an avian influenza that had adapted to human hosts. Alarmingly, it was strikingly similar to the H1N1 strain of swine influenza that affected much of the world in 2009. ${ }^{2}$

\section{Origin and spread of the pandemic}

The virulent strain of influenza responsible for so many deaths is believed to have first broken out in August 1918 in military camps in western France and southern England, but there is some evidence that it may have originated in crowded military camps in the United States, before travelling with the troops across the Atlantic to France. ${ }^{3}$ The virus spread rapidly throughout the Allied and German armies, killing thousands of troops on both sides of the Western Front. It soon dispersed throughout Europe's civilian population via the railways, roads and waterways, killing more than 2 million people, including about 200,000 in England and Wales, 240,000 in France and a similar number in Germany and perhaps 450,000 in Russia. ${ }^{4}$ In Spain about 260,000 people died. That country remained neutral during the war and, unlike most of the combatant nations, did not impose press censorship. News of the ravages of influenza there spread around the world; that is why it became known as 'Spanish flu'. ${ }^{5}$ The virus crossed the Atlantic in August and within a few months about 675,000 Americans had died, more than the United States lost in all its wars of the twentieth century. ${ }^{6}$ By the time of the Armistice in November 1918, the virus was raging across the globe, spread across the continents by trains and cars and across the oceans by ships. It is estimated that 18 million people may have died in India and perhaps 10 million in China. In Indonesia the death toll was about 1.5 million. Millions more died across South America and Africa. It is estimated that 300,000 people died in South Africa. ${ }^{7}$

2 Taubenberger et al., 'Reconstruction of the 1918 Influenza Virus'.

3 Crosby, America's Forgotten Pandemic, 37-38; Johnson, 'Britain and the 1918-19 Influenza Pandemic', 37-46;

Erkoreka, 'Origins of the Spanish Influenza Pandemic'.

4 Johnson, 'Britain and the 1918-19 Influenza Pandemic', 80.

Johnson, 'Britain and the 1918-19 Influenza Pandemic', 137-38.

Johnson, 'Britain and the 1918-19 Influenza Pandemic', 79; Crosby, America's Forgotten Pandemic, 207.

Johnson, 'Britain and the 1918-19 Influenza Pandemic', 78-79. 
Most people are familiar with influenza's symptoms: a sore throat, severe cough, shivering fits, headaches and muscular pain, vomiting and diarrhoea. The symptoms of 'Spanish' Influenza were the same, only more severe. The attack commonly lasted 3 or 4 days but it left its victims weak and debilitated for weeks afterwards. However, it was not the influenza that caused the high number of fatalities but the pneumonial complications that developed in about 10 or 20 per cent of cases. In those days, prior to the discovery of antibiotics, the only treatment for pneumonia was complete bed-rest and careful nursing, but even then the mortality rate was usually about 30 per cent. ${ }^{8}$ In those flu-sufferers who developed pneumonia, infection attacked the respiratory membranes and blood vessels in the lungs, causing the lungs to fill with blood and fluid. Fever and delirium set in and the patient usually lapsed into a coma. The body began to darken due to greatly reduced blood oxygen levels, and death usually occurred within another day or two. In particularly severe cases, a fit, healthy young man who complained of a sore throat in the morning might lapse into a coma by lunchtime and be dead by nightfall. After death the body would continue to darken and sometimes turned completely black. For this reason the epidemic was sometimes known as the 'Black Flu' .' Mortality from influenza is usually confined to the very young and the elderly, but the 1918-19 pandemic caused a disproportionate number of deaths among those aged between 25 and 44, particularly men. ${ }^{10}$ Infection rates were relatively low for people aged over 50 , possibly the result of immunity acquired through exposure to an earlier pandemic.

When news came in October 1918 from South Africa of the high death toll there, the Australian Government imposed strict quarantine procedures at all ports. ${ }^{11}$ Australian troops returning home from the war, especially those aboard ships that stopped in South Africa en route, were quarantined aboard their ships in port or in isolation camps such as Torrens Island, near Port Adelaide, until it was clear that none were infected. While these measures failed to stop the pandemic reaching Australia, they delayed it significantly, by which time its virulence seems to have diminished; the virus had evidently mutated into a less virulent strain than the one that had raged around the world in late $1918 .^{12}$

It was, however, still very dangerous when it reached Australia. About 12,000 Australians died from influenza, including 540 in South Australia. ${ }^{13}$ The mortality rate in Australia was about 2.3 deaths per 1,000, the lowest of any Western nation. The rate in South Australia was 1.2 per 1,000, the lowest of any mainland state. Tasmania established its own strict quarantine that caused great disruption to its

8 Rice, Black November, 24.

9 Rice, Black November, 7, 23-24.

10 Curson and McCracken, 'An Australian Perspective of the 1918-1919 Influenza Pandemic', 104-5.

11 Cumpston, Influenza and Maritime Quarantine; Camm, 'The "Spanish” Influenza Pandemic', 13-14.

12 Crosby, America's Forgotten Pandemic, 234; Rice, Black November, 200.

13 Commonwealth of Australia, Official Year Book, 1920, 1128-9. A more recent estimate puts the death toll in Australia at about 14,500 (Johnson, 'Britain and the 1918-19 Influenza Pandemic', 81). 
economy, but it emerged at the end of 1919 with the lowest recorded mortality rate in the world. ${ }^{14}$ In contrast, the New Zealand Government failed to establish any effective quarantine procedures. Influenza slipped into Auckland Harbour in October 1918, when the virus was still at its most virulent, and within 2 months it had killed about 8,000 people, including more than 2,000 Māoris. The mortality rate among non-indigenous New Zealanders was about 6 per 1,000, but for Māori people it was 7 times higher. ${ }^{15}$ Where medical care was available, the death rate among Māoris was relatively low; but in isolated communities where nearly everyone was suddenly struck down, leaving no one to care for the sick or provide food and water, whole villages were virtually wiped out. ${ }^{16}$

The influenza pandemic had devastating effects on many of the indigenous communities of the Pacific Ocean that, at that time, still had had relatively little contact with the outside world and thus had little opportunity to acquire immunity to diseases common elsewhere. Influenza reached the island of Guam in October 1918 and most of the American navy personnel became ill. Only one American died, but there were 800 deaths among the local islanders, a mortality rate of 45 per 1,000. In Tahiti there were 600 deaths among the islanders, a mortality rate over 150 deaths per $1,000 .^{17}$

A New Zealand ship, the SS Talune, with several infected crew members and passengers on board, sailed into Apia Harbour in Western Samoa in November 1918. The New Zealand authorities there failed to quarantine the ship and over the next 2 months about 7,500 Samoans died, about 20 per cent of the population. ${ }^{18}$ Australia despatched a team of doctors and nurses but they could do little to help. ${ }^{19}$ The authorities in neighbouring American Samoa established strict quarantine regulations that kept that island group virtually free of influenza. Meanwhile, the Talune sailed on, with some infected Samoans on board, to Fiji where 5,000 people died, and to Tonga and Nauru, where thousands more died. ${ }^{20}$

The Australian Government established a policy of 'reverse quarantine' in relation to its Pacific territories. Ships leaving Australian ports for the Pacific had to remain in port until medical authorities were sure there was no infection on board. Australia also established strict quarantine procedures for ships entering ports

14 Rice, Black November, 263.

15 Rice, Black November, 160-61; Mamelund, 'Geography May Explain Adult Mortality', 48.

16 Rice, Black November, 159-83.

17 Crosby, America's Forgotten Pandemic, 232; Shanks, Hussell and Brundage, 'Epidemiological Isolation';

Mamelund, 'Geography May Explain Adult Mortality', 48.

18 Crosby, America's Forgotten Pandemic, 232.

19 Sydney Morning Herald, 25 November 1918, 6; Sydney Morning Herald, 17 February 1919, 8.

20 Herda, 'Disease and the Colonial Narrative', 135-38; Johnson, 'Britain and the 1918-19 Influenza Pandemic', $50-51,82,123$. 
in New Guinea and the other territories. Those procedures prevented influenza reaching New Guinea, and probably saved many thousands, perhaps tens of thousands of lives there. ${ }^{21}$

In Western countries, the mortality rate ranged from about 2 per 1,000 (in Australia) up to 10 per 1,000 (in Italy). The mortality rate for indigenous people was in a different league, ranging from Fiji at 30 per 1,000 and New Zealand Māoris at about 40 deaths per 1,000 up to Western Samoa at 200 per 1,000. In 1947, a United Nations report declared that the epidemic in Western Samoa was 'one of the most disastrous epidemics recorded anywhere in the world during the present century, so far as the proportion of deaths to the population is concerned'. ${ }^{22}$

\section{Influenza comes to Australia}

Despite the strict quarantine imposed by the Commonwealth Government, the influenza virus arrived in Melbourne in January 1919, probably with troops returning from the war. Some of the troops subsequently travelled home to Sydney, taking the virus with them. Over the next 10 or 11 months, the virus spread, in several waves, across the continent, to all the capital cities and larger regional centres and to many smaller country towns and outback settlements. As I noted earlier, at least 12,000 Australians died from influenza during that period.

New South Wales (NSW) was particularly hard hit by the epidemic, recording more than 6,000 deaths, including about 3,500 deaths in the Sydney metropolitan area. About a third of Sydney's population became infected; factories, offices and schools were closed, hospitals filled to overflowing, sporting events and religious services were curtailed and victory parades for returning troops were cancelled. The sick were quarantined in their own homes or admitted to isolation hospitals. The mortality rate in NSW was about 3 deaths per 1,000. Inner-city suburbs such as Glebe, Balmain and Redfern recorded rates in excess of 5 deaths per 1,000 but in nearby Homebush the rate rose to nearly 10 deaths per 1,000 . North Shore suburbs had mortality rates just below the state average, while exclusive Vaucluse recorded only 3 deaths among its 3,000 residents. In general, mortality rates were lower in the country than in the city, but Newcastle, Broken Hill and other mining towns had high death rates, as did other large country centres such as Lithgow and Goulburn. ${ }^{23}$

\footnotetext{
21 Burnet and Clarke, Influenza, 74; Crosby, America's Forgotten Pandemic, 234; Shanks, Hussell and Brundage, 'Epidemiological Isolation'.

22 New Zealand History, 'The 1918 Influenza Pandemic: Page 10 - Influenza in Samoa', nzhistory.govt.nz/ culture/1918-influenza-pandemic/samoa.

23 McQueen, 'The "Spanish" Influenza Pandemic'; Camm, 'The "Spanish” Influenza Pandemic'; McCracken and Curson, 'Flu Downunder'.
} 
By late 1919 the influenza epidemic had abated from most of Australia, but early in 1920 there was another wave that affected many Aboriginal people in the Northern Territory, Cape York Peninsula and the Torres Strait islands and, a few months later, a milder epidemic that struck Sydney and country NSW, and caused a few dozen deaths. These 1920 outbreaks, like others elsewhere in the world at that time, are considered to be the final wave of the 1918-19 pandemic. $^{24}$

\section{'Spanish' Influenza in South Australia}

In 1920, the Registrar-General of Births, Deaths and Marriages in South Australia reported that 532 deaths in 1919, comprising 303 males and 229 females, were the direct result of the influenza epidemic, and he considered that 'some hundreds' more were attributable to the effects of influenza. ${ }^{25}$ The Commonwealth Year Book in 1920 assessed the death toll in South Australia as $540 .{ }^{26}$ It appears that neither of these sources included Aboriginal people in their statistics.

Adelaide's first influenza cases were reported in late January 1919. As Western Australia remained free of the disease, passenger trains were cancelled on the EastWest line. Freight trains continued to run between Perth and Adelaide, but the crews were changed at the state border to prevent the infection spreading. A special ward was established at the Adelaide Hospital to care for the sick but the 40 beds there were soon filled and an isolation hospital was hurriedly established by the Central Board of Health in the Exhibition Building on North Terrace. ${ }^{27}$ Severely ill patients were sent to the isolation hospital, but less severe cases could remain at home. Doctors and nurses were then in short supply, as many were still to return from military service overseas. With a large proportion of the population ill with influenza and hospitals overflowing, local doctors and nurses worked tirelessly treating the sick.

In Australia it was well-known that the pandemic was having devastating effects around the world. Newspapers regularly reported the mounting death toll in Europe, South Africa and the United States. On 14 February, the Adelaide Register published a report from The Times of London that estimated that 6 million people had died worldwide from influenza during the preceding 3 months. ${ }^{28}$

\footnotetext{
24 Crosby, America's Forgotten Pandemic, 203; Erkoreka, 'Origins of the Spanish Influenza Pandemic', 190.

25 SA, Registrar-General of Births, Deaths and Marriages, Annual Report, 1920, 6.

26 Commonwealth of Australia, Official Year Book, 1920, 1129. Woodruff refers to 563 South Australian deaths from Spanish Influenza, but does not cite the source of that information. Woodruff, Two Million South Australians, 59.

27 Woodruff, Two Million South Australians, 65.

28 Register, 14 February 1919, 8.
} 
By the middle of March there were no new cases being reported in South Australia, and it was thought that perhaps the worst was past. To that point there had been only about 30 deaths. Almost immediately, however, there was a severe outbreak in Port Pirie, which had its own sea-links with the eastern states, and a new wave of cases across Adelaide. By the end of April, the isolation hospital in the Exhibition Building was treating more than 250 patients. ${ }^{29}$ Newspapers printed weekly reports on the condition of the patients there, with each patient identified by a number so that relatives and friends could keep track. The weekly bulletins also listed the death toll for each week, and the locations of new outbreaks.

The first wave of the flu lasted from February to July and claimed about 300 lives, ${ }^{30}$ more than half of them in Adelaide. Working-class areas in the western suburbs and the city's West End had the highest infection rates. ${ }^{31}$ There were major outbreaks in the Mid-North, South-East and Yorke Peninsula in April and May. Isolation hospitals had to be established in each town or district suffering an outbreak. Schools, halls or other public buildings were commandeered for the purpose. On Yorke Peninsula, all public events were cancelled to prevent the spread of infection. Port Pirie was particularly hard-hit. The virus appeared there in late March and within 2 weeks there were more than 200 cases, and 19 deaths, including the district nurse. The Central Board of Health ordered the closure of all schools, churches and places of entertainment in the Port Pirie district, and restricted all travel in the area. About 30 people there died during May and June. ${ }^{32}$ The virus also spread, probably via train crews, to Peterborough and other railway towns in the Mid-North, and to Broken Hill, where there were at least 60 deaths from influenza between May and October. ${ }^{33}$

The epidemic reached Queensland in May and Western Australia in June, when the flu in South Australia seemed to be abating. However, in August there was another serious outbreak in Adelaide, and by September the virus had spread across much of the state, to the Mid-North, the southern Flinders Ranges, River Murray and Yorke Peninsula. The Register on 4 September reported that there were about 200 people ill at Murray Bridge, and more than 60 cases at Orroroo in the Mid-North. ${ }^{34}$ There was a late outbreak at Streaky Bay and Denial Bay in early October, but by the end of that month the virus was largely gone from South Australia.

\footnotetext{
29 Woodruff, Two Million South Australians, 72-74.

30 Register, 12 August 1919, 4.

31 Kako, 'Spanish influenza of 1918-19', 51.

32 Woodruff, Two Million South Australians, 72-73; Kako, 'Spanish influenza of 1918-19', 53.

33 Camm, 'The "Spanish" Influenza Pandemic', 22. My research using Trove indicates about 60 deaths in Broken Hill.

34 Register, 4 September 1919, 8.
} 


\section{South Australian Aboriginal people and the 'Spanish' Influenza epidemic}

The official death toll for South Australia of 540 people does not include Aboriginal deaths. The Chief Protector of Aborigines, William South, did not specifically record details of Aboriginal deaths during the epidemic, but Aborigines Department records, newspapers and other historical sources provide some insights into the way influenza spread through the Aboriginal population (see Figure 1), and the final death toll.

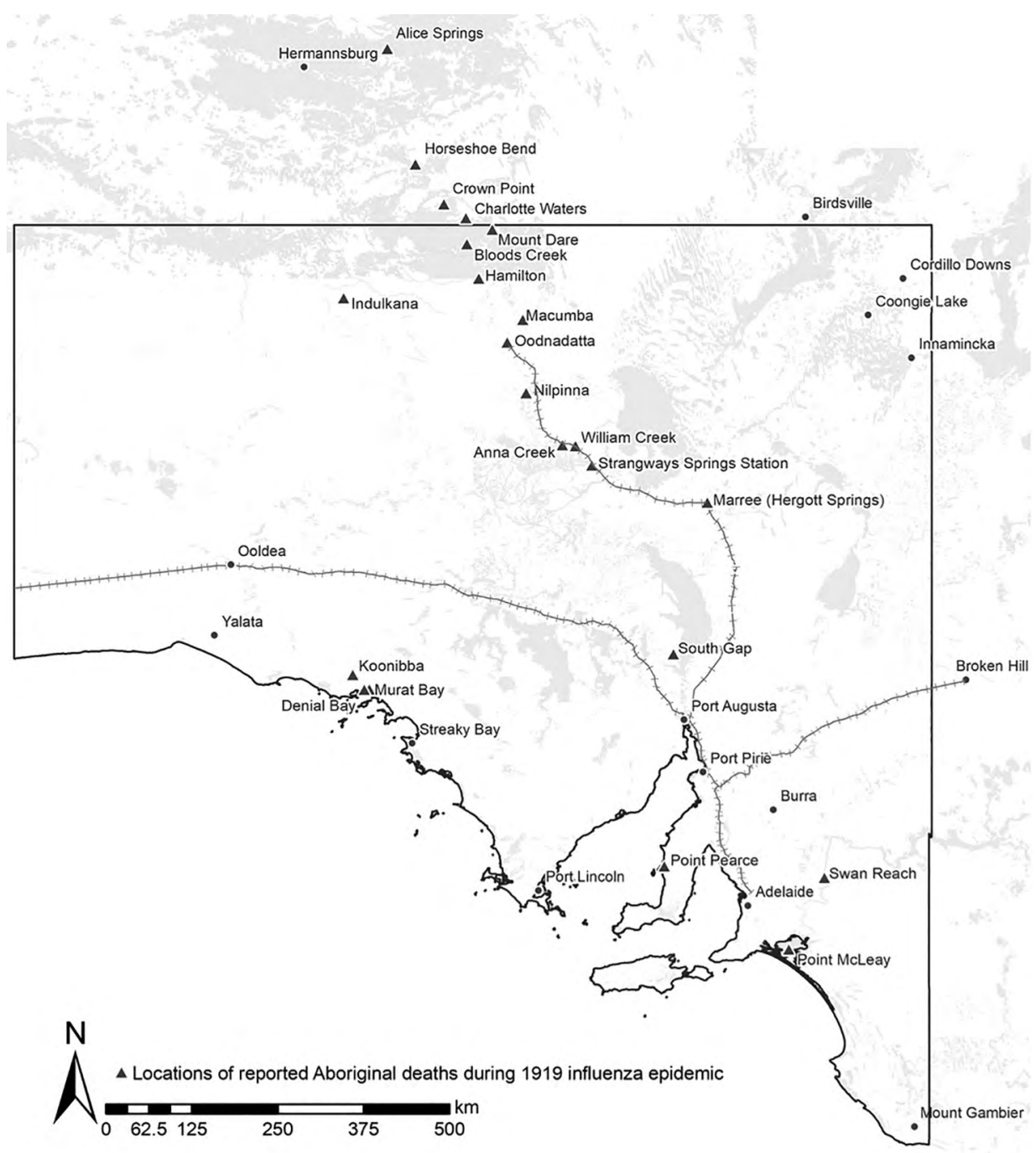

Figure 1: Locations of Aboriginal deaths from influenza in 1919, and other locations mentioned in the text.

Source: Drawn by Marc Thomas using ArcGIS, location data from data.gov.au. 
Chief Protector William South ensured that both Point McLeay and Point Pearce stations were quarantined when outbreaks threatened - no visitors were allowed to enter and residents were not permitted to leave. As a result of those measures, both stations escaped the first wave unscathed. In the second wave, in August, 50 out of about 200 residents at Point Pearce became ill, but there was only one death. ${ }^{35}$ At Point McLeay many of the 300 residents, and most of the staff, were infected. The Chief Protector despatched a nurse to assist and there were only 2 deaths recorded at the station. ${ }^{36}$ There were apparently no other Aboriginal deaths reported in the South-East, nor along the River Murray, except at Swan Reach. The local policeman there advised the Chief Protector in August that all but one of the 40 Aboriginal people in the district were ill with influenza. He had done all he could to assist them, but there had been 2 deaths. ${ }^{37} \mathrm{~A}$ newspaper noted that most of the shearing in that district was usually done by Aboriginal shearers, and, 'owing to the outbreak of influenza among the natives', shearing in the area had been delayed. ${ }^{38}$

Further to the north there was an outbreak of influenza in Port Augusta in July, which resulted in several deaths among the white residents. ${ }^{39}$ There were no reported deaths in the Aboriginal fringe camps there and there is no evidence of influenza spreading westwards or north-westwards to affect Barngarla and Kokatha people working on the pastoral stations in the Gawler Ranges and on Eyre Peninsula. In August some shearers from Port Augusta took the flu with them to South Gap Station, near Lake Torrens, and most of the white workers there became ill. The virus spread to the 'blacks' camp' on the station where at least 2 people died: Tommy Yunda, aged 70, the so-called 'king' of the tribe, and his wife, Minnie, aged $64 .{ }^{40}$ Influenza caused several deaths among white residents at Hawker and Quorn, but it apparently did not spread further to affect Adnyamathanha people in the northern Flinders Ranges.

\section{Influenza in northern South Australia and central Australia}

In the north of the state, the influenza epidemic took a heavy toll on Aboriginal people. The virus spread northwards along the railway from Peterborough in early June, reaching Marree and then Oodnadatta, the end of the line at that time. In July a correspondent of the Adelaide Daily Herald who had just returned from the north reported:

35 SA Aborigines Department, GRG 52/1/1919/31.

36 SA Aborigines Department, GRG 52/1/1919/64; see also Advertiser, 23 August 1919, 11.

37 SA Aborigines Department, GRG 52/1/1919/65.

38 Register, 29 August 1919, 3.

39 See, for example, Advertiser, 18 June 1918, 9; Daily Herald, 18 June 1919, 2.

40 Transcontinental, 29 August 1919, 2. 
[Influenza] seemed to break out among the whites after the running of the Oodnadatta mixed train some six weeks or so ago. The whole crew of train men got it and one engine-driver died. It went through the towns of Farina, Marree, William Creek and Oodnadatta, and is now among the blacks. At William Creek there was a camp of six blacks. They all took ill and although the acting stationmaster took them a little food and did what he could they died one by one, and the stationmaster and the engine-drivers and firemen who happened to be there at the time had to bury them. The last to die, poor old Romeo, hung out till early this week, and when the stationmaster called to see how he was he found him dead ... They are also dying at Oodnadatta, and it looks as though there will be few blacks left alive if it continues to spread. They will not keep themselves warm. As soon as their temperature rises off go blankets and clothes and out they go. ${ }^{41}$

In Marree, 80 white residents became sick, but there were no reported deaths. There were many deaths, however, in the Afghan camps and, according to one source, Aboriginal people there too were 'dropping dead like flies' ${ }^{42}$ The disease spread northwards along the railway line to Strangways Springs where, according to a newspaper account, 17 Aboriginal people died. ${ }^{43}$ There were more deaths at William Creek and Anna Creek, and in the Aboriginal camps around Oodnadatta. ${ }^{44}$ The Chief Protector despatched tarpaulins, blankets and medicine for an isolation camp on the town's outskirts. Dr Tackaberry, the local doctor, took charge of the isolation camp and he was assisted over the next few weeks by the local policeman and a number of the residents, including the Australian Inland Mission (AIM) padre, Rev. Harland, and the AIM nurses, Sisters Williamson and Harvey (see Figure 2). ${ }^{45}$ Dr Tackaberry advised the Chief Protector in early July:

influenza is still prevalent among the Aborigines. There have been about 15 deaths in this immediate district, several at William Creek and others in various other parts. Since I have erected the isolation camp there has been a marked improvement and it has proved well worth the trouble and expense. Out of about 20 patients now under observation there has been but three deaths. These were very serious when brought in. ${ }^{46}$

41 Daily Herald, 17 July 1919, 3.

42 Stevens, Tin Mosques and Ghantowns, 251.

43 Register, 29 August 1919, 5.

44 Quorn Mercury, 19 December 1919, 4.

45 Bullen, Nursing in the Desert, 63-102.

46 SA Aborigines Department, GRG 52/1/1919/50. 


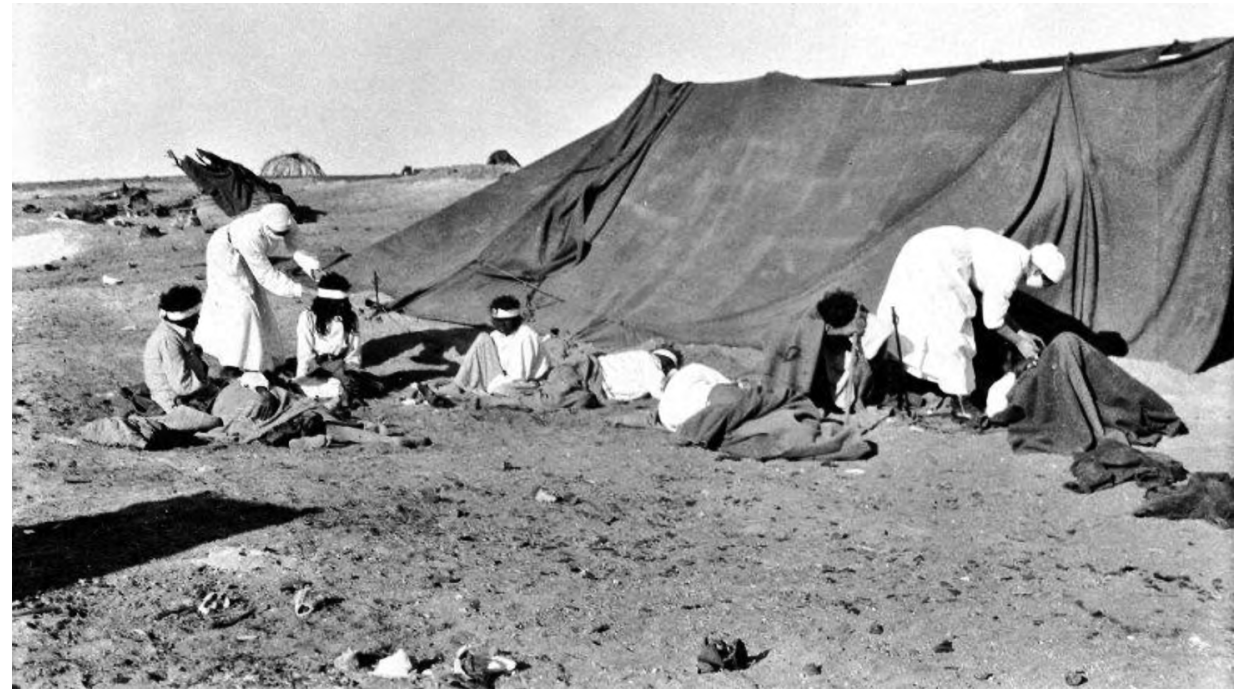

Figure 2: AIM nurses Sister Harvey (left) and Sister Williamson (right) treat Aboriginal patients at the Oodnadatta isolation hospital.

Source: Photograph from Rev. C. Harland Collection, courtesy Heatheranne Bullen.

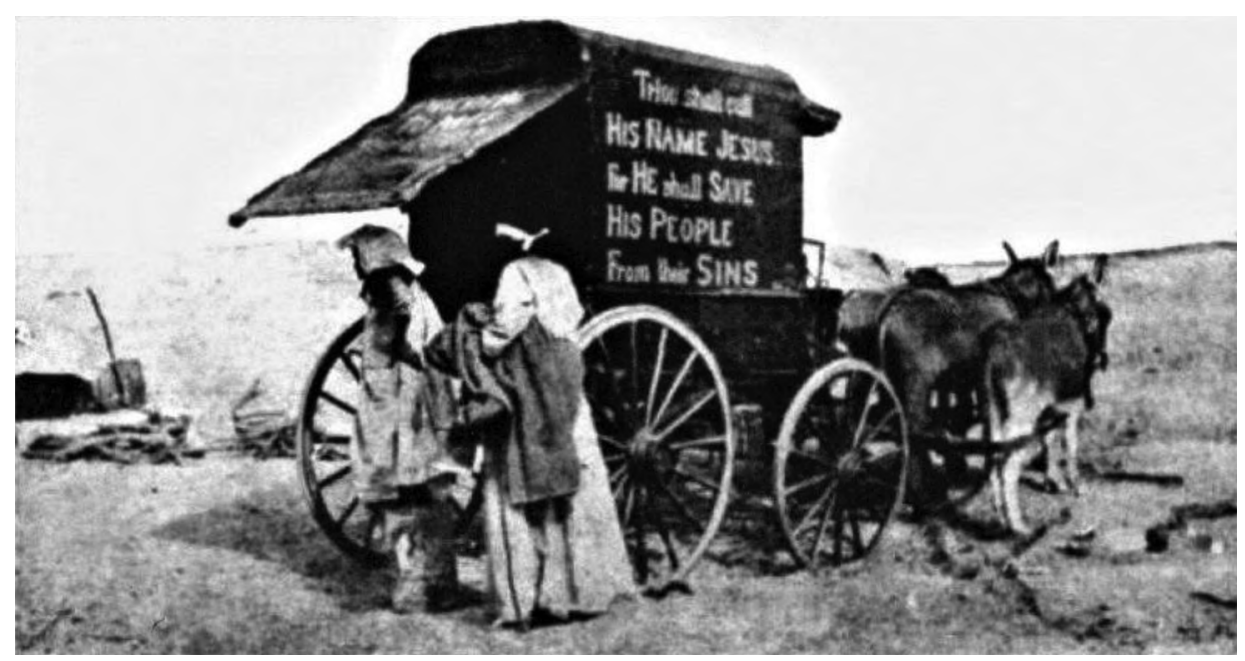

Figure 3: 'Two sick lubras alighting from itinerant preacher's van at the isolation area, Oodnadatta'. Rev. Kramer used his caravan to transport Aboriginal patients to the isolation hospital.

Source: Photograph from Observer, 16 August 1919, 28. 
Rev. Ernest Kramer, an 'itinerant missionary' connected with the Aborigines' Friends' Association in Adelaide, arrived in Oodnadatta with his wife, Euphemia, just after the epidemic struck, and they both helped to treat the sick (see Figure 3). He wrote:

Oh, such sadness and such sights as I shall never forget. They were so neglected and helplessly dying like animals, but with the doctor's and the policeman's help we rigged up an isolation camp outside the town, and then, with four donkeys in the van, the sick were gathered into camp and cared for.

My heart was full of pain, for the sight was sad indeed. Many were carried in one day in hope, and carried out later a corpse. A hole was dug out of the town, then the body was rolled in its blankets and buried, many without the knowledge of a Saviour, without hope in God. Some were so terrified that after their first night in camp, they ran away, choosing to die in the bush country.

Nursing and caring for those alive, we had a busy time for about six weeks, until the epidemic ceased, losing not an opportunity to teach them of the great love of Jesus, who died to save us all. ${ }^{47}$

A resident of Oodnadatta, Horrie Simpson, recalled:

When the Asian [sic] flu hit Oodnadatta in the winter of 1919 some white people went down with it but it was the Aboriginal community that copped it badly, especially the older ones. A big tent, made of railway canvases, was erected at the end of the line and in this the Aborigines were hospitalized and cared for. The huge tent was partitioned off, half for men and the other for women. Those who offered their services to attend the sick were Mr Harland of the AIM, Mounted Constable Percy Welsh, Nurse Kelly and Mr Leo Kelly. These people tended the sick, washed them, and put clean clothes on them, placed the convalescents in the sun and spread out the blankets daily on the gibbers.

The main trouble was with the patients who wouldn't stop in bed and would rush into the cold air, causing a lot to die. Little white mounds leading eastward from the railhead mark their graves. Some of the older men thought their illness was caused by the death bone pointed at them, others thought the white fellows were doing them more harm than good and tried to escape. One young man, Rufus by name, disappeared from the temporary hospital and turned up at Todmordon Station some sixty miles away. He lived to tell the tale. ${ }^{48}$

47 Kramer, Australian Caravan, 13-14.

48 Simpson and Dallwitz, Horrie Simpson's Oodnadatta, 9. 
A correspondent of the Quorn Mercury at Oodnadatta suggested that the Aboriginal belief in sorcery contributed to some of the deaths, but also acknowledged that others died from grief at the loss of friends and relatives:

One very useful and educated boy recently confided in his employer that he had been 'boned', and there is little hope held out for his recovery. He has been laid up for several days with influenza, and remains in a perpetual state of delirium. Just how many of the fatal cases were the victims of this obsession it would be hard to say, for the aboriginal is not communicative to the white man. It became known, however, that the natives had formed the belief that the white man had poisoned them, and the whole black race had been doomed for extinction. It is improbable, however, that all thought this the case ... One old lubra wandering back to a wurlie a hundred yards or so from the isolation area, and asked where she had been, replied, 'Me bin longa Mary's grave. Me bin cry a little bit. Byembye me go longa cry little bit more'. An old native who had lost his lubra through 'flu was 'too much sorry' to take any further interest in life, and soon followed her to the grave. Two lubras who had been inseparable friends died within a day of each other - the one from 'flu, and the other from apparently the just as dangerous condition of 'too much sorry'. ${ }^{49}$

The spread of the disease would have been facilitated by the overcrowded conditions in the camps around Oodnadatta, as Bruce Shaw, an oral historian, pointed out. One of his informants, Miriam Dadleh, remembered the 'black influenza':

my mother died when I was about ten. That was 1919. That big influenza, 'black influenza' they called it. Returned boys came back you know from the 1914-18 war? Well that's the time that they came back that that flu went through like raided [sic] Aboriginal people and Afghan people and white people and all, up that way. My Dad caught it. He went to meet one of his old friends, Ernie Kempe from Macumba Station. He went and shaking hands and old Ernie Kempe was returned soldier and he was a bit sick. And old man got a germ off him and went back. My mother just had a baby see ... He was born in 1918 and Mum died in 1919.50

Herbert Basedow, an Adelaide medical doctor and anthropologist, led 3 medical relief expeditions among Aboriginal people in South Australia between 1919 and 1920. He visited Marree and Oodnadatta in 1920 and reported that influenza had caused many deaths among the local Aboriginal people. He wrote:

49 Quorn Mercury, 9 January 1920, 3.

50 Shaw, Our Heart Is the Land, 73. 
The recent influenza epidemic was disastrous, having in many centres, like Hergott Springs [Marree] and Oodnadatta, almost completely annihilated the resident groups. We were surprised also to note the appalling decrease in the numbers at Anna Creek, once a veritable stronghold of the local tribe. ${ }^{11}$

It was customary for Aboriginal people to immediately vacate a camp where someone had died. Basedow was told that terror-stricken groups had fled Oodnadatta and other settlements for the bush, only to become ill themselves a few days later, when they were far from help. If the whole group was struck down and there was nobody left to find food or water for the sick, or firewood for warmth, few people would survive.

During the early years of the twentieth century, Aboriginal ration depots had been established at Oodnadatta and at Nilpinna, William Creek and Anna Creek pastoral stations further south. Rations were supplied there to the aged, infirm and sick by the Aborigines Department. The ration-issuer was required to provide to the Protector monthly returns showing the number of Aboriginal people at the station, and any births and deaths that had occurred.

These returns indicate that in the 3 years between January 1916 and December 1918 there were usually about 60 to 70 Aboriginal people in Oodnadatta, although this figure sometimes increased to 100 or more and was sometimes as low as 11 . Thirteen deaths were recorded during that period, at an average of about 4 per year. The policeman there recorded 7 deaths in June 1919 and 18 more in July, a total of 25 deaths in 2 months, about 6 times the annual average.

Nilpinna Station, south of Oodnadatta, had been an Aboriginal ration depot since about 1906. The records sent in by the ration-issuer there indicate that from 1912 to 1920 there were on average about 20 people there each month receiving rations; sometimes there were 40 people, sometimes as few as 10 . From 1912 to 1918, on average, there were about 1.5 deaths per year there. In June and July 1919, when the flu struck Oodnadatta, the ration-issuer at Nilpinna recorded a total of 10 deaths, about 6 times above the average annual rate. ${ }^{52}$ Further south at Anna Creek Station, the ration records indicate that there were 14 deaths in June, and at William Creek, further south again, there were at least 6 deaths. ${ }^{53}$ It is likely that most of these deaths can be attributed to influenza. At Marree, however, where Aboriginal people were reported to have 'dropped dead like flies' and where influenza had, in Basedow's words, 'almost completely annihilated the resident groups', the ration records indicate only one Aboriginal death in June and another in July.

51 Basedow, 'Report upon the Third Medical Relief Expedition', 4-5.

52 SA Aborigines Department, GRG 52/26.

53 SA Aborigines Department, GRG 52/26. The 6 deaths at William Creek were confirmed in the Daily Herald, 17 July $1919,3$. 
Luise Hercus, a linguist who recorded oral histories from Arabana, Wangkangurru and other Aboriginal people from the Lake Eyre Basin, observed that the influenza epidemic 'wiped out whole families and even whole groups, particularly those camped by the railway line for rations'. Her Wangkanguru informant, Mick McLean, recalled:

he had left a cherished sacred object, a necklace belonging to the Intara History, with some old people camped at the Big Kadnyawi Spring near Mount Dutton [about $40 \mathrm{~km}$ south-east of Oodnadatta]. When he returned some months later he found the entire group had been wiped out by influenza; the sand had blown from the nearby sandhill and buried them and the whole deserted camp..$^{54}$

Walter Smith, an Aboriginal drover and bushman, passed through Wire Creek Bore, just north of Oodnadatta, in 1919 when the epidemic was raging. His biographer, Dick Kimber, an Alice Springs historian, wrote:

the Bore was a place of sad memories for Walter. Here, during the great influenza epidemic of 1918 [sic] which decimated the central Australian tribes, Walter had come across families who had died. They had caught the influenza at Oodnadatta and, in its earliest stages with some of the people still in good health, had begun to walk to Dalhousie Springs. Dalhousie was the great healing centre for all the surrounding tribes, the place where two kinds of 'minty bush' grew which enables strongly scented smoke to be inhaled, and where sulphurous smokes were made. The families only managed 35 kilometres of their 100 kilometre walk when they made camp at Wire Creek Bore. There they all died. Many people of European descent died during the influenza epidemic, but the effect was far more devastating in the Aboriginal communities. The tears trickled down Walter's face as he remembered the men, women and children who had died. He never again made camp at Wire Creek Bore. ${ }^{55}$

Kimber noted that the epidemic brought to an end the large ceremonial gatherings of the type seen by Walter Smith in 1915 near Old Crown Point Station, when about 500 Southern Arrernte, Arabana and Wangkangurru people gathered. ${ }^{56}$

Kim Doohan, an anthropologist who worked with Aboriginal people at Finke in the 1980s, talked to a senior Aboriginal woman there who recalled the epidemic:

[she] was a young girl living on Macumba Station when the 'flu took big mob, they bin too frightened for whitefella medicine, went bush whole lot, anangu [Aboriginal people] bin die that way, Mt. Dare, Macumba, Hamilton and Blood Creek'. She had contracted 'the flu' and recalls how her father

54 Hercus, A Grammar of the Arabana-Wangkangurru Language, 22.

55 Kimber, Man from Arltunga, 53.

56 Kimber, Man from Arltunga, 56. 
wrapped her in a blanket, 'people really weak, no tucker only kapi [water], that's all'. She slept by the fire until she was well. Many died in their swags by the camp fires, 'too many to bury proper way'. ${ }^{57}$

From Oodnadatta, influenza also spread along the bush tracks westwards to reach Granite Downs and Indulkana, then the very limit of the pastoral frontier. The police constable stationed at Indulkana reported that it had caused about 20 deaths among the Aboriginal people there. ${ }^{58}$ The virus may have been taken there by the mailman from Oodnadatta.

In November 1919, in his annual report for the year ended 30 June 1919, Chief Protector William South stated that the outbreak of influenza in the Oodnadatta area had resulted in 16 Aboriginal deaths at the isolation camp and about 20 at other places' ${ }^{59} \mathrm{He}$ also acknowledged that 'it was more than likely that others died, whose cases did not come under the doctor's notice'. The 20 other deaths to which South referred may have been the 14 fatalities at Anna Creek and the 6 fatalities at William Creek recorded in his department's ration records. He apparently did not acknowledge the 10 deaths at Nilpinna, the 17 deaths at Strangways Springs nor the 20 deaths at Indulkana. In his annual report the following year, covering the last 6 months of 1919, he did not refer to the epidemic. The known death toll in the north of the state was thus about 83 . There were many other deaths, however; those who 'dropped dead like flies' in Marree and those who, stricken with terror, fled Oodnadatta to die at Wire Creek Bore and other spots in the bush, and others who died further north at Mt Dare, Macumba, Hamilton and Bloods Creek. I consider it likely that at least 130 Aboriginal people died along the railway/telegraph line between Marree and the South Australian border.

Influenza also spread northwards into the Northern Territory along the overland track, probably carried by telegraph linesmen, Afghan cameleers and other travellers. Many Arrernte people at Crown Point, just over the border in the Northern Territory, and at Charlotte Waters and Horseshoe Bend died. The owner of Horseshoe Bend Station later reported:

The blacks here died like flies, and it was the same everywhere, all the way down to Oodnadatta. ${ }^{60}$

The disease reached Alice Springs in August and killed 53 Aboriginal people there, as well as several white residents. ${ }^{61}$ Dr Basedow stated that the epidemic had 'wrought havoc' in central Australia, and the number of deaths at Alice Springs and Horseshoe

57 Doohan, One Family, Different Country, 18.

58 SA Aborigines Department, GRG 52/1/1919/83.

59 SA, Chief Protector of Aboriginals, Annual Report, 1919, 5.

60 Strehlow, Journey to Horseshoe Bend, 158-59.

61 Scherer, The Hermannsburg Chronicle, 40. 
Bend was 'particularly great'. ${ }^{62}$ The Lutheran missionaries at nearby Hermannsburg believed their mission was spared only by 'the grace of God'. ${ }^{63}$ According to the anthropologist T. G. H. Strehlow:

The Spanish influenza epidemic of 1919-20 wiped out the bulk of the ageing, chronically undernourished population in the Southern and Central Aranda areas, and made serious inroads elsewhere. After 1920 full-scale ceremonial festivals were rarely held either in these parts, or among the Eastern Aranda, who had suffered almost as cruelly. ${ }^{64}$

There was clearly a focus of infection along the Oodnadatta railway and the telegraph line to Alice Springs, affecting mainly Arabana, Wangkangurru and Arrernte people, as well as Antakarinya people, recent immigrants to the Oodnadatta area from the north-west. Apart from the outbreak at Indulkana, there is no evidence that the epidemic spread to the remote sheep stations north-west of Oodnadatta. Perhaps the short incubation period and the quick onset of severe symptoms meant that anyone infected - Aboriginal or non-Aboriginal - did not get too far from the telegraph line before they became too ill to travel further, and therefore could not spread the disease to people on the more remote stations.

\section{Influenza on the west coast of South Australia}

Influenza reached South Australia's west coast in August, probably spread there by coastal shipping. Many white residents were infected and 4 died, including the Streaky Bay doctor. The virus spread to the Aboriginal fringe-camps around Denial Bay, where 5 people died, and Murat Bay, where 8 more died. ${ }^{65}$ The Register reported in early October that at Denial Bay there were about 20 Aboriginal people sick with flu:

One was buried on Monday, and white residents had to assist in the burial owing to the blacks being too weak to complete the grave. Tarpaulins are urgently required for shelter, as the weather is very cold and windy. Patients are lying in the open, and they include a girl about three years old. The natives break up the camps as soon as a death occurs and residents are doing their best to assist them. The blacks are too weak to procure their own food, and have applied to the Protector for financial assistance. ${ }^{66}$

Nearly 100 adults and 67 children at Koonibba mission, as well as many of the staff, went down with the flu. The Chief Protector later reported 9 deaths at the mission, all of them adult 'full blacks'. ${ }^{67}$ A local newspaper reported a total of 23 Aboriginal

62 Basedow, 'Medical Inspection of Natives', 44.

63 Lohe, 'A Mission Is Established', 32.

64 Strehlow, Songs of Central Australia, xxxv.

65 West Coast Sentinel, 18 November 1919, 2.

66 Register, 2 October 1919, 8; see also SA Aborigines Department, GRG 52/1/1919/77, 80, 81.

67 SA, Chief Protector of Aboriginals, Annual Report, 1920, 15. 
deaths on the west coast: 9 at Koonibba, 5 at Denial Bay, 8 at Murat Bay and one at Bagster. ${ }^{68}$ It is likely that there were other deaths that went unreported. There is no evidence that influenza spread further west to Fowlers Bay or beyond to the Nullarbor Plain, or northwards to Ooldea on the East-West Railway.

\section{Influenza in north-eastern South Australia}

A number of secondary sources suggest that many Aboriginal people died when influenza spread down Cooper Creek in north-eastern South Australia in 1919. A newspaper article published in 1937 states:

The Far-west [of Queensland] has cause to remember the 1919 plague of pneumonic influenza; the legacy of battle that crossed the oceans and came to Australia by way of New Zealand. The Cooper blacks died by scores, despite the care and nursing they had at Nappamerrie and other Cooper stations. ${ }^{69}$

In 1950, George Farwell, a noted travel-writer, stated:

in 1920 [sic] ... when influenza was an epidemic sweeping the world, it was noted along the Birdsville Track that the blacks were dying fast. ${ }^{70}$

However, Dr Basedow traversed this region between August and November 1919, visiting Innamincka, Birdsville, Mungerannie, Cordillo Downs and other stations, and he reported no signs of influenza. He observed that the people there:

were fortunately spared the unhappy lot of their western neighbours at Oodnadatta, Marree (Hergott Springs) and other places where the disease swept away numbers of the population. ${ }^{71}$

There are no reports of Aboriginal deaths from influenza in the north-east in the Aborigines Department records in 1919 or 1920, and I believe that 'Spanish' Influenza did not reach that area.

In June and July 1923 there was a serious epidemic of pneumonic influenza that caused about 40 deaths in Brisbane and other fatalities in Sydney and Melbourne. ${ }^{72}$ The virus seems to have spread inland as far as south-west Queensland, where it caused much sickness, and a few deaths, among white residents at Goondiwindi, Charleville and Longreach. ${ }^{73}$ It reached Bedourie and Boulia, north of Birdsville, where the Aboriginal communities 'suffered severe outbreaks of influenza', according

68 West Coast Sentinel, 18 October 1919, 2.

69 Courier-Mail, 28 August 1937, 20.

70 Farwell, Land of Mirage, 116-17.

71 Basedow, 'Report upon the First Medical Relief Expedition', 55.

72 Brisbane Courier, 21 July 1923, 7.

73 Longreach Leader, 22 June 1923, 13; Brisbane Courier, 28 June 1923, 9; Sydney Morning Herald, 28 July 1923,

14; Toowoomba Chronicle and Darling Downs Gazette, 28 July 1923, 7; Western Champion, 25 August 1923, 15. 
to the Queensland Chief Protector. ${ }^{74}$ It appears that it was this epidemic that reached the Cooper Creek area, in early July. Its effects on the Aboriginal people there were documented by the Chronicle's correspondent at Innamincka. He wrote, on 7 July:

For some weeks there has been an epidemic of colds. Four old blacks at one of the Innamincka Station camps died and were buried by a couple of younger aboriginals, who also became affected. In a couple of days another black and five gins passed out, the three or four remaining alive being too weak to move. At Coongy Lakes, 60 miles out, where many blacks are now congregated, all hands seem to be suffering with the same complaint. Two or three deaths have taken place there also. ${ }^{75}$

On 18 July the correspondent advised:

Influenza is still raging. Six more blacks at Coongy Lakes passed away this week, and a number of others were suffering. ${ }^{76}$

About 2 weeks later, he advised that influenza was 'still prevalent':

It is most severe out Coongy Lakes way, where four more natives have passed off, making the number of deaths there twelve. At Cordillo Downs Station many are suffering. ${ }^{77}$

The correspondent again reported on 9 August that 'fifteen blacks of the Coongy tribe died from influenza'. ${ }^{78}$

The disease spread to the white workers on Cordillo Downs. ${ }^{79} \mathrm{Mr}$ Murray, the manager of the station for 23 years, retired in 1924 . He told a newspaper reporter:

Influenza, which was prevalent in the district two years ago, killed a lot of them [Aboriginal people], particularly the old ones. ${ }^{80}$

Lou Reese, the owner of Minnie Downs Station, wrote to the South Australian Museum's anthropologist, Norman Tindale, in 1927, describing the condition of Aboriginal people in that region:

In this district they are dying out very quickly. The influenza epidemic a few years ago must have accounted for over a hundred. That's from Kanowna and Innamincka north to the border fence. ${ }^{81}$

\footnotetext{
74 Qld, Chief Protect of Aboriginals, Annual Report, 1923, 5.

75 Chronicle, 21 July 1923, 14.

76 Chronicle, 4 August 1923, 13.

77 Chronicle, 11 August 1923, 14.

78 Chronicle, 18 August 1923, 15.

79 Argus (Melbourne), 28 March 1924, 14.

80 Register, 27 November 1924, 3.

81 Letter from L. Reese to N. B. Tindale, 17 November 1927, AA 298/4/2/2, South Australian Museum Archives.
} 
There is also a reference to many Aboriginal deaths at Arrabury Station, in western Queensland, which may relate to the 1923 epidemic. ${ }^{82}$ It is evident that at least 10 Aboriginal people died at Innamincka and another 15 at Coongie Lakes, and there were additional deaths at Cordillo Downs, Minnie Downs and Arrabury, and probably at other neighbouring stations.

According to Hercus, Murtee Johnny, who died in 1977, was the last survivor of the Yandruwanda group in the Strzelecki area; he told her that his wife and children and the rest of the group had died at Innamincka during an influenza epidemic that she believed was the 1919 epidemic. ${ }^{83}$ Hercus subsequently agreed that those deaths could have occurred during this later epidemic, in $1923 .{ }^{84}$

Basedow's report indicates that influenza did not reach the north-east of the state in 1919. The Aboriginal people who died in that area were probably victims of a subsequent epidemic in 1923, not the 1919 event. The 2 epidemics have evidently become conflated in oral history and published accounts.

\section{The Aboriginal death toll}

I suggested previously that at least 130 people may have died along the railway/ telegraph line in northern South Australia. With the addition of 23 recorded deaths on the west coast, plus another 10 or so unrecorded deaths there, plus the other recorded deaths at Point McLeay, Point Pearce, Swan Reach and South Gap, the death toll across the whole state may have been 160 or more. Aborigines Department records suggest that the death toll was certainly more than 100 .

The Chief Protector's annual reports in the first decades of the twentieth century include the number of Aboriginal births and deaths recorded each year (see Figure 4). There is no indication in the Chief Protector's files how these figures were obtained. I consider it likely that the figures were compiled from the monthly returns filled out by the ration-issuers on the various pastoral stations, police stations, missions and reserves. The average number of Aboriginal deaths in the state during the 5 years preceding the 1919 epidemic was about 70 per annum. During the year ending 30 June 1919, there were 107 deaths, an increase of about 50 per cent on the average annual death toll of the pre-epidemic years. In the following year, the figure rose to 160, an increase of more than 100 per cent on the pre-epidemic years. ${ }^{85}$ Although these official figures could hardly be considered reliable, they indicate that there

82 Western Grazier, 6 March 1942, 3.

83 Hercus, "How We Danced the Mudlunga”, 27.

84 Luise Hercus, pers. comm., 30 November 2013 and 8 April 2014.

85 The Chief Protector's annual reports are available online at 'South Australia: Legislation / Key Provisions' AIATSIS, aiatsis.gov.au/collection/featured-collections/remove-and-protect. 
were about 130 more deaths among the Aboriginal population during 1919 than there were, on average, during the preceding 5 years. After 1920, the Chief Protector did not include the number of births and deaths in his annual reports.

The Inspector of Police in Port Augusta, who was also the Sub-Protector of Aborigines for the Far North (including the west coast), reported annually on the number of Aboriginal deaths in that region (see Figure 4). During the 4 years prior to the epidemic, he reported about 20 deaths each year. ${ }^{86}$ Those figures, too, could not be considered reliable; the Sub-Protector was reliant on the returns from his officers at Oodnadatta, Marree, Indulkana and other police stations, and Aboriginal people, customarily, were reluctant to speak of their dead. However, from an average of about 20 deaths per year previously, the death toll jumped to 122 in the year ending 30 June 1920, an increase of about 100 over the pre-epidemic years. This figure probably includes the deaths along the railway line in northern South Australia, the 2 at South Gap as well as those on the west coast, and provides support for the statewide figure of about 130 additional deaths from influenza suggested by the Chief Protector's annual reports. The Sub-Protector's figures were probably compiled from the reports sent in to him by the police at Oodnadatta, Indulkana, Marree and on the west coast but do not, of course, include unreported deaths in the bush.

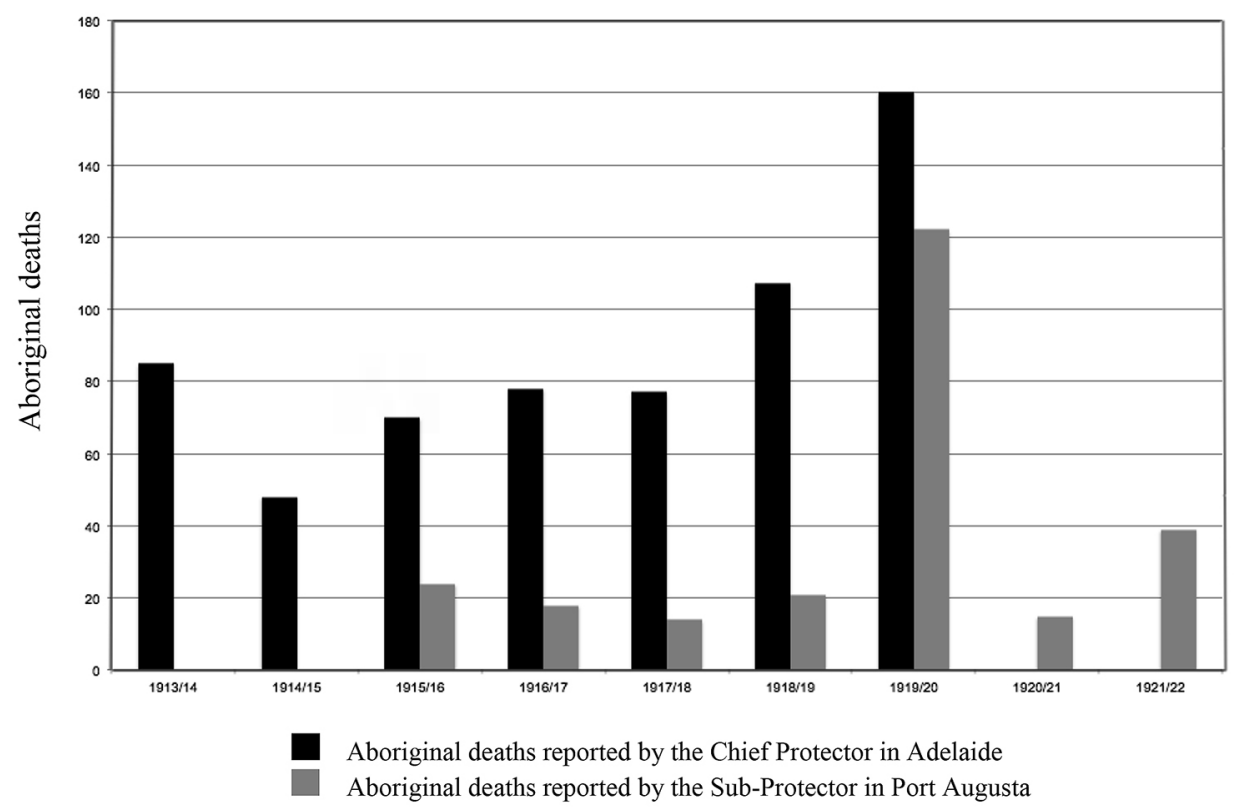

Figure 4: Aboriginal deaths in South Australia 1913-22.

Note: no statistics available from the Chief Protector for 1920-21 or 1921-22 or from the Sub-Protector in Port Augusta for 1913-14 or 1914-15.

Source: Aborigines Department annual reports.

86 The Sub-Protector's annual reports are included in the Chief Protector's annual reports. 
The Chief Protector estimated that the Aboriginal population of South Australia on 30 June 1919 was $4,815 .{ }^{87}$ If we assume that the statewide Aboriginal death toll from influenza was 130 , the mortality rate for Aboriginal people was about 27 per 1,000 , about 20 times higher than the rate for non-Indigenous South Australians. If the actual death toll was 160 , then the mortality rate was about 33 per 1,000, about 28 times higher than that of the non-Indigenous population.

If we look more specifically at northern South Australia, an even more alarming statistic is revealed. Assuming that 500 Aboriginal people lived in the vicinity of the railway and telegraph line between Marree and the Northern Territory border - probably a generous estimate - and assuming that that there were 130 influenza deaths in that area, then the mortality rate was about 260 per 1,000 ; about 25 per cent of the Aboriginal population perished. Similar mortality rates were recorded in some Aboriginal settlements in Queensland. ${ }^{88}$ The 1919 epidemic had little impact on Aboriginal people in southern South Australia, who probably had some immunity gained from exposure to previous influenza epidemics. In the far north and west of the state, Aboriginal people had little or no previous exposure to influenza and thus little or no immunity. Their immunity may have been further compromised by malnutrition and the effects of venereal disease, tuberculosis and other chronic diseases. ${ }^{89}$ Most of South Australia's Aboriginal people were spared the worst effects of the epidemic, but for those who lived in the camps along the railway and the overland telegraph line or on the adjoining pastoral stations, the epidemic was devastating. The sickness and deaths were seared into the memories of the Aboriginal survivors, as the oral histories recorded by Kimber, Hercus, Shaw, Doohan and others demonstrate.

Official figures cited by Briscoe indicate that the epidemic was responsible for the deaths of 315 Aboriginal people in Queensland, including 69 deaths at the Barambah settlement, and 31 at Taroom..$^{90}$ No detailed historical research has previously been undertaken into the effects of 'Spanish' Influenza on Aboriginal people in the other states and the Northern Territory. A search on the Trove digitised newspapers website ${ }^{11}$ indicates that influenza spread to many Aboriginal missions and communities in New South Wales but the number of fatalities was not great; 12 deaths were reported at Kyogle, 5 at Casino, 6 at Taree and others here and there around the state. ${ }^{92}$ The epidemic's effects seem to have been most severe in western NSW where at least 30 Aboriginal deaths were reported at Brewarrina, Wellmoringle,

\footnotetext{
87 SA Chief Protector of Aboriginals, Annual Report, 1920, 4.

88 Cleland, 'Disease among the Australian Aborigines', 65; Curson and McCracken, 'An Australian Perspective of the 1918-1919 Influenza Pandemic',105.

89 Dowling, 'A Great Deal of Sickness', 216, 222-24.

90 Briscoe, Queensland Aborigines and the Spanish Influenza Pandemic; see also Cleland, 'Disease among the Australian Aborigines', 66; Basedow, 'Diseases of the Australian Aborigines', 9.

91 Trove, National Library of Australia, trove.nla.gov.au/newspaper/.

92 Daily Examiner, 6 March 1919, 5; Kyogle Examiner, 17 May 1919, 2; Northern Champion, 26 July 1919, 4.
} 
Dennawan and Cultowa. ${ }^{93}$ The NSW Aborigines Protection Board declared that the mortality rate was 'surprisingly low'.$^{94}$ In Victoria there were very high infection rates among the Aboriginal people at Corranderk and other reserves and missions, but, according to the Board for the Protection of Aborigines, not a single death. ${ }^{95}$

Briscoe has suggested that there were at least 150 Aboriginal influenza deaths in Western Australia. ${ }^{96}$ Newspaper reports show that between August and October there were Aboriginal deaths reported across the Goldfields, the south-west and in the Perth area and there were also a number of deaths at Geraldton, Mullewa and Boolardy Station in the Murchison district. ${ }^{97}$ In November there was a severe outbreak in Broome, where about 30 Aboriginal people died. Influenza spread to the Beagle Bay and Lombadina missions late in 1919, where there were at least 50 deaths. ${ }^{98}$ It reached Darwin, where at least 10 Aboriginal people died, and spread from there southwards as far as Pine Creek, causing about 50 deaths. ${ }^{99}$ There is evidence that it caused some fatalities in the Tiwi Islands, ${ }^{100}$ and newspapers report more than 40 deaths on Thursday Island and other Torres Strait islands in February 1920, as well as numerous fatalities at Aboriginal settlements on the western side of Cape York Peninsula. ${ }^{101}$

It is likely that at least 1,000 Aboriginal people throughout Australia died from influenza in 1919-20. Mortality rates among Aboriginal people in southern Australia were generally low, but in those areas where influenza gained a foothold among Aboriginal people who had little immunity - in central Australia, northern and outback Queensland, and in the Kimberley, the top end of the Northern Territory and the Torres Strait Islands - the mortality rate was high, comparable to those of indigenous people elsewhere around the world.

When the Commonwealth Government introduced, in 2008, the Australian Health Management Plan for Pandemic Influenza (AHMPPI), the national strategy to respond to a future - and probably inevitable - influenza epidemic, no special provisions were made for Aboriginal people. Medical authorities involved in developing the plan were apparently unaware of the high Aboriginal mortality rate

\footnotetext{
93 Leader, 9 July 1919, 2; Grenfell Record and Lachlan District Advertiser, 8 August 1919, 2.

94 NSW Aborigines Protection Board, Aborigines, Report, 1920.

95 Herald, 4 January 1921, 12.

96 Briscoe, Counting, Health and Identity, 132.

97 Murchison Times and Day Dawn Gazette, 27 June 1919, 2; West Australian, 28 July 1919, 5; Geraldton Guardian, 19 August 1919, 3; Great Southern Herald, 23 August 1919, 3; Tambellup Times, 23 August 1919, 3; Southern Argus and Wagin-Arthur Express, 30 August 1919, 2; Geraldton Guardian, 11 September 1919, 2; Laverton and Beria Mercury, 4 October 1919, 1; Leonora Miner, 11 October 1919, 2.

98 West Australian, 25 February 1920, 7.

99 West Australian, 18 December 1919, 6; Northern Territory Times and Gazette, 5 February 1920, 1; Advertiser, 14 February 1920, 9.

100 Peterson and Taylor, 'Demographic Transition', 14, 17.

101 Telegraph, 21 February 1920, 2; Register, 21 February 1920, 7. Huggonson ('Aborigines and the Aftermath of the Great War', 4) also refers briefly to influenza deaths in the Torres Strait and Cape York Peninsula.
} 
during the 1919 epidemic and the high infection and hospitalisation rates among Aboriginal people during the 1957 'Asian influenza' pandemic. ${ }^{102}$ High infection and hospitalisation rates among Aboriginal and Torres Strait Islander people during the 2009 'swine flu' epidemic, and advocacy by Indigenous communities and their health organisations prompted the Commonwealth and state/territory health authorities to develop special measures for Aboriginal and Torres Strait Islander people and other 'at risk' groups in its revised AHMPPI issued in 2014. ${ }^{103}$

In this paper I have focused on the impact of the epidemic on South Australian Aboriginal people. Detailed research using Trove and other documentary sources mission and government records, and oral histories - are likely to provide additional insights into the way the epidemic spread across the continent, and its impact on Indigenous people in the other states and the Northern Territory. Historical research not only increases our understanding of past epidemics but also has the potential to contribute to shaping the national response to a future epidemic.

\section{Postscript June 2020}

I first came across references to deaths from Spanish Influenza in the Oodnadatta area when I was doing historical research for a native title claim in northern South Australia in the 1990s. Over subsequent decades I found more references to the impact of the pandemic in South Australia in Aborigines Department records, local histories, Aboriginal oral histories, newspapers and other sources. In 2019 I decided it was time to write up what I had found and submit it for publication. I hoped to publish it that year, in the centenary of the pandemic, and it was accepted for publication in Aboriginal History. I was putting the finishing touches to it in early January, when south-eastern Australia was engulfed by bushfires. And then came the coronavirus pandemic, and the world went into lockdown. It is now the end of June, and most of Australia is emerging from the restrictions imposed in late March on travel, social gatherings, sports and cultural events and so on. Most of the remote Aboriginal communities in South Australia, Western Australia and the Northern Territory - and some not so remote ones here in South Australia such as Davenport, Point Pearce, Gerard and Nepabunna - opted to restrict access to their lands, requiring all people (except for essential personnel) who wished to enter or re-enter the communities to self-isolate for 14 days prior to entry. There have

\footnotetext{
102 Miller, Durrheim and Aboriginal and Torres Strait Islander Community Influenza Study Group, 'Aboriginal and Torres Strait Islander Communities Forgotten', 316-17.

103 Australian Government '2.4 Seasonal Influenza, Pandemic Influenza and Pneumonia', 19 December 2013, www1. health.gov.au/internet/publications/publishing.nsf/Content/cda-cdi37suppl.htm -02-vpds 2-4-influenza; SA Health, 'Viral Respiratory Disease Pandemic Response Plan (including influenza, COVID-19, SARS \& MERS)', 2020, www. sahealth.sa.gov.au/wps/wcm/connect/a7539fe7-7d39-43e0-920d-94ac63983796/SAH_Viral_Respiratory_Disease_ Pandemic_Response_Plan_final.pdf?MOD=AJPERES\&amp;CACHEID=ROOTWORKSPACE-a7539fe7-7d3943e0-920d-94ac63983796-niRcgJQ.
} 
been no cases of coronavirus reported in these communities or elsewhere in central Australia. Now that travel between SA, WA and the NT is to be opened up, some of the desert communities are opting out of the restrictions, while others have decided to retain them for a while longer at least. Those communities that have opted out have reserved the right to reimpose restrictions should coronavirus cases occur in the region.

Across the world there have been over 10 million infections from coronavirus, and the death toll has topped 500,000. While many countries have 'flattened the curve', the infection rate is still rising alarmingly in the United States, Brazil, India and Indonesia. As far as I can tell from publicly available data, the fatality rate per 1,000 people is presently about 0.38 in the USA, 0.57 in Italy, 0.60 in Spain and 0.64 in the United Kingdom. During the 1918-19 pandemic, the fatality rate in those countries was at least 10 or 20 times higher. So far Australia has escaped relatively lightly, as it did in the 1918-19 pandemic. We have had just over 100 deaths nationally and the fatality rate is 0.004 per 1,000 . The New Zealand Government, aware of that country's disastrous experience in 1918-19, imposed one of the most severe lockdown regimes in the world and by early June had eliminated the virus from the country. The Pacific Island nations that suffered so badly a century ago imposed travel bans and other lockdown measures in March and have largely remained free of the virus. Samoa, which suffered 7,500 deaths in 1918-19 has remained fatality-free. Here in Australia, most of the states and territories have had no new cases for several weeks. The plans to reopen state borders have, however, been thrown into disarray by new outbreaks in Melbourne and there is widespread concern about a possible 'second wave'. Some epidemiologists and other medical experts have suggested that the 2 or 3 waves of influenza that were reported in the UK, USA, Australia and other countries in 1918-19 were each the natural result of premature relaxation of what we now know as 'social distancing' rules. The future is very uncertain, and many people, me included, are worried about what may happen over the next few months.

\section{References}

\section{Primary sources}

\section{Archives}

Basedow, Herbert. 'Medical Inspection of Natives of Southern Portion of NT'. Commonwealth Home and Territories Department, NAA A3 NT1922/2805. National Archives of Australia. 
Basedow, Herbert. 'Report upon the First Medical Relief Expedition amongst the Aborigines of South Australia'. SA Public Works Department, GRG 23/1/144/1920. State Records South Australia.

Basedow, Herbert. 'Report upon the Third Medical Relief Expedition among the Aborigines of South Australia'. SA Public Works Department ,GRG 23/1/330/1921. State Records South Australia.

SA Aborigines Department. GRG 52/1, Correspondence. State Records of South Australia.

SA Aborigines Department. GRG 52/26, Depot Ledgers. State Records of South Australia.

South Australian Museum Archives. AA 298/04, Correspondence - Anthropological \& Archaeological, Vol. 1.

\section{Newspapers}

The Advertiser (Adelaide)

The Argus (Melbourne)

Brisbane Courier

Chronicle (Adelaide)

Courier-Mail (Brisbane)

Daily Examiner (Grafton, NSW)

Daily Herald (Adelaide)

Geraldton Guardian (WA)

Great Southern Herald (Katanning, WA)

Grenfell Record and Lachlan District Advertiser (NSW)

The Herald (Melbourne)

Kyogle Examiner (NSW)

Laverton and Beria Mercury (WA)

Leader (Orange, NSW)

Leonora Miner (WA)

Longreach Leader (Qld)

Murchison Times and Day Dawn Gazette (WA)

Northern Champion (Taree, NSW)

Northern Territory Times and Gazette (Darwin)

Quorn Mercury (SA)

The Register (Adelaide)

Southern Argus and Wagin-Arthur Express (WA)

Sydney Morning Herald (NSW)

Tambellup Times (WA)

Telegraph (Brisbane) 
Toowoomba Chronicle and Darling Downs Gazette (Qld)

Transcontinental (Port Augusta, SA)

West Australian (Perth)

West Coast Sentinel (Streaky Bay, SA)

Western Champion (Barcaldine)

Western Grazier (Wilcannia, NSW)

\section{Secondary sources}

Basedow, Herbert. 'Diseases of the Australian Aborigines'. Journal of Tropical Medicine and Hygiene, 15 June to 15 September, 1932: 1-32.

Briscoe, Gordon. Counting, Health and Identity: A History of Aboriginal Health and Demography in Western Australia and Queensland, 1900-1940. Canberra: Aboriginal Studies Press, 2003.

Briscoe, Gordon. Queensland Aborigines and the Spanish Influenza Pandemic of 1918-1919. Research Discussion Paper (Australian Institute of Aboriginal and Torres Strait Islander Studies) No. 3/1996. Canberra: Aboriginal Studies Press, 1996.

Bullen, Heatheranne. Nursing in the Desert: Oodnadatta, Australia 1919. Ballarat, Vic.: The author, 2019.

Burnet, Frank Macfarlane and Ellen Clarke. Influenza. Melbourne: Macmillan, 1942.

Camm, Jack. 'The "Spanish" Influenza Pandemic: Its Spread and Pattern of Mortality in New South Wales during 1919'. Australian Historical Geography 6 (1984): 13-25.

Cleland, John Burton. 'Disease among the Australian Aborigines'. Journal of Tropical Medicine and Hygiene 6, no. 31 (1928): 65-70.

Commonwealth of Australia. Official Year Book of the Commonwealth of Australia, 1920. Melbourne: Government Printer, 1920.

Crosby, Alfred W. America's Forgotten Pandemic: The Influenza of 1919. Cambridge: Cambridge University Press, 1989.

Cumpston, J. H. L. Influenza and Maritime Quarantine in Australia. Melbourne: Government Printer, 1919.

Curson, Peter and Kevin McCracken. 'An Australian Perspective of the 1918-1919 Influenza Pandemic'. NSW Health Bulletin 17, nos 7-8 (2006): 103-7. doi.org/10.1071/NB06025.

Doohan, Kim. One Family, Different Country: The Development and Persistence of an Aboriginal Community at Finke, Northern Territory. Oceania Monograph No. 42. Sydney: University of Sydney, 1992. 
Dowling, Peter J. “'A Great Deal of Sickness”: Introduced Diseases among the Aboriginal People of Colonial Southeast Australia 1788-1900'. PhD thesis, The Australian National University, 1997.

Erkoreka, Anton. 'Origins of the Spanish Influenza Pandemic (1918-20) and Its Relation to the First World War'. Journal of Molecular and Genetic Medicine 3, no. 2 (2009): 190-94. www.ncbi.nlm.nih.gov/pmc/articles/PMC2805838/. doi.org/10.4172/17470862.1000033 .

Farwell, George. Land of Mirage: The Story of Men, Cattle and Camels on the Birdsville Track. Adelaide: Rigby, 1950.

Hercus, Luise A. A Grammar of the Arabana-Wangkangurru Language, Lake Eyre Basin, South Australia. Pacific Linguistics Series C-128 (Research School of Pacific and Asian Studies). Canberra: The Australian National University, 1994.

Hercus, Luise A. "'How We Danced the Mudlunga": Memories of 1901 and 1902'. Aboriginal History 4, no. 1 (1980): 5-32. doi.org/10.22459/AH.04.2011.01.

Herda, P. S. 'Disease and the Colonial Narrative: The 1918 Influenza Pandemic in Western Polynesia'. New Zealand Journal of History, 34, no. 1 (2000): 133-44.

Huggonson, David. 'Aborigines and the Aftermath of the Great War'. Australian Aboriginal Studies 1993/1 (1993): 2-9.

Johnson, Niall. Britain and the 1918-19 Influenza Pandemic: A Dark Epilogue. Oxford: Routledge, 2006. doi.org/10.4324/9780203018163.

Johnson, Niall P. A. S. and Juergen Mueller. 'Updating the Accounts: Global Mortality of the 1918-1920 "Spanish" Influenza Pandemic'. Bulletin of the History of Medicine 76 (2002): 105-15. doi.org/10.1353/bhm.2002.0022.

Kako, Mayumi, Malinda Steenkamp, Philippa Rokkas, Olga Annikeeva and Paul Arbon. 'Spanish Influenza of 1918-19: The Extent and Spread in South Australia'. Australian Epidemiologist 22, no. 1 (2015): 48-54.

Kimber, Richard G. Man from Arltunga: Walter Smith, Australian Bushman. Victoria Park, WA: Hesperian Press, 1986.

Kramer, Ernest E. Australian Caravan Mission to Bush People and Aboriginals: Journeyings in the Far North and Centre of Australia. Melbourne: Self-published, c. 1921.

Lohe, Max. 'A Mission Is Established at Hermannsburg'. In Hermannsburg: A Vision and a Mission, edited by E. Leske, 6-41. Adelaide: Lutheran Publishing House, 1977.

McCracken, Kevin and Peter Curson. 'Flu Downunder: A Demographic and Geographic Analysis of the 1919 Pandemic in Sydney, Australia'. In The Spanish Influenza Pandemic of 1918-19: New Perspectives, edited by H. Phillips and D. Killingray, 110-32. London: Routledge, 2003. 
McQueen, Humphrey. 'The 'Spanish' Influenza Pandemic in Australia, 1912-19'. In Social Policy in Australia: Some Perspectives 1901-1975, edited by Jill Roe, 131-47. Stanmore, NSW: Cassell Australia, 1976.

Mamelund, Svenn-Erik. 'Geography May Explain Adult Mortality from the 1918-1920 Influenza Pandemic’. Epidemics3 (2011):46-60. doi.org/10.1016/j.epidem.2011.02.001.

Miller, A., A. D. Durrheim and Aboriginal and Torres Strait Islander Community Influenza Study Group. 'Aboriginal and Torres Strait Islander Communities Forgotten in New Australian National Action Plan for Human Influenza Pandemic: "Ask Us, Listen to Us Share with Us"'. Medical Journal of Australia 193, no. 6 (2010): 316-17. doi.org/ 10.5694/j.1326-5377.2010.tb03939.x.

New South Wales Aborigines Protection Board. Aborigines, Report of Board for the Protection of, for the period 1st January 1919 to 30th June 1920. Sydney: Government Printer, 1920. aiatsis.gov.au/sites/default/files/docs/digitised_collections/remove/23673.pdf.

Peterson, Nic and John Taylor. 'Demographic Transition in a Hunter-Gatherer Population: The Tiwi Case, 1929-1996'. Australian Aboriginal Studies 1 (1998): 11-27.

Phillips, Howard and David Killingray. 'Introduction'. In The Spanish Influenza Pandemic of 1918-19: New Perspectives, edited by H. Phillips and D. Killingray, 1-26. London: Routledge, 2003.

Queensland. Aboriginal Department. Report upon the Operations of certain Sub-Departments of the Home Secretary's Department - Aboriginal Department, Information contained in Report for the Year ended 31st December, 1923. Brisbane: Queensland Parliament, 1923. aiatsis.gov.au/sites/default/files/docs/digitised_collections/remove/64132.pdf.

Rice, Geoffrey W. Black November: The 1918 Influenza Epidemic in New Zealand. Christchurch, NZ: Canterbury University Press, 2005.

Scherer, Philipp A. The Hermannsburg Chronicle 1877-1933. Tanunda, SA: Self-published, 1995.

Shanks, G. D., T. Hussell and J. F. Brundage. 'Epidemiological Isolation Causing Variable Mortality in Island Populations during the 1918-1920 Influenza Pandemic'. Influenza and Other Respiratory Viruses 6, no. 6 (2012): 417-23. doi.org/10.1111/j.1750-2659. 2011.00332.x.

Shaw, Bruce. Our Heart Is the Land: Aboriginal Reminiscences of the Lake Eyre Basin. Canberra: Aboriginal Studies Press, 1995.

Simpson, Horrie and John Dallwitz. Horrie Simpson’s Oodnadatta. Oodnadatta, SA: Oodnadatta Progress Association, 1990.

South Australian Chief Protector of Aboriginals. Annual Reports. Adelaide: Government Printer, 1914-1920.

South Australian Registrar-General of Births, Deaths and Marriages. Annual Report. South Australian Parliamentary Papers, no. 19, 1920. 
Stevens, Christine. Tin Mosques and Ghantowns: A History of Afghan Camel Drivers in Australia. Melbourne: Oxford University Press, 1989.

Strehlow, Theodore G. H. Journey to Horseshoe Bend. Sydney: Angus \& Robertson, 1969.

Strehlow, Theodore G. H. Songs of Central Australia. Sydney: Angus \& Robertson, 1971.

Taubenberger, Jeffrey K., David Baltimore, Peter C. Doherty, Howard Markel, David M. Morens, Robert G. Webster and Ian A. Wilson. 'Reconstruction of the 1918 Influenza Virus: Unexpected Rewards from the Past'. mBio 3, no. 5 (2012): doi.org/10.1128/mBio. 00201-12.

Woodruff, Philip. Two Million South Australians. Adelaide: Peacock Publications, 1984. 
This text is taken from Aboriginal History, Volume 43, 2019, edited by Ingereth Macfarlane, published 2020 by ANU Press, The Australian National University, Canberra, Australia.

doi.org/10.22459/AH.43.2019.01 